\title{
A DEMOCRACIA NA PERSPECTIVA DE ALGUNS TEÓRICOS MARXISTAS
}

\author{
MARIA JOSÉ DE REZENDE *
}

\begin{abstract}
REZENDE, M.J. de A democracia na perspectiva de alguns teóricos marxistas. Semina: Ci. Sociais/Humanas, Londrina, v. 17, n. 3, p. 274-285, set. 1996.
\end{abstract}

RESUMO: Este artigo mapeia as principais posições de alguns teóricos filiados ao marxismo sobre a democracia e sua relação com o socialismo. Buscou-se, a partir das reflexões desenvolvidas na primeira metade do século $X X$, elucidar as especificidades de um debate vigoroso que se desenvolveu naquele momento. Isto forneceu os elementos para a compreensão das questões fundamentais que foram levantadas, na segunda metade deste século, por uma parte do movimento socialista ocidental que se voltou com grande ênfase para a necessária imbricação entre a democracia política e o socialismo.

PALAVRAS-CHAVE: Democracia, socialismo, Estado, capitalismo, classe trabalhadora, instituições políticas, representação.

\section{Introdução}

Este trabalho é uma reflexão sobre as mais importantes teorizações acerca da relação socialismo e democracia. Por esta razão, a análise destacará os debates que floresceram na primeira metade deste século. No entanto, não se restringirá a eles, pois pretende-se compreender os rumos tomados por estas discussões após a década de 1950.

É importante ressaltar, mesmo não se tratando do tema que será desenvolvido, que as teorias pluralistas e elitistas apresentam a democracia como algo indissociável do capitalismo, ou seja, como parte de seu próprio processo de organização. Essa equalização foi feita também por algumas vertentes teóricas da esquerda.

Para a teoria liberal, a democracia deriva"do mercado. Seu funcionamento aparece como um mecanismo do mesmo, que se expressa na sua forma mais acabada na concorrência entre partidos nos moldes da concorrência empresarial.

No campo da esquerda, a vertente leninista é a expressão mais acabada da desconsideração e do desprezo para com a questão da democracia. Aqueles que seguiram à risca os escritos de Lênin como $O$ Estado e a revolução e $A$ revolução proletária e o renegado Kautsky sempre insistiram no argumento de que a democracia burguesa é hipócrita.

Parte-se aqui da necessidade de distinguir democracia e capitalismo. Este é o pressuposto básico, uma vez que o problema do qual se pretende dar conta é o da relação entre socialismo e democracia. A busca de consubstancialidade entre estes dois últimos discorda, no entanto, das duas pressuposições anteriores, tanto a liberal quanto a leninista.

A não-equalização entre democracia e capitalismo foi feita pela social-democracia no início deste século. Por isso tomamos as suas discussões como base das reflexões sobre o significado da democracia na passagem ao socialismo.

Serão enfatizados os escritos de Kautsky, Bernstein, Bauer, Adler e Rosa de Luxemburgo quanto à problemática específica da relação socialismo e democracia até o final da segunda década ${ }^{1}$ deste século. Como será visto, este foi o período mais fecundo desta discussão. Esta questão estava presente nos diversos debates sobre a forma de encaminhamento da revolução russa; era um tema presente nas reflexões sobre os caminhos e descaminhos da revolução. Para exemplificar, basta citar J. O. Martov do partido Mencheviques que argumentava no livro Ditadura e democracia, em 1919, que o único pré-requisito político para o socialismo era a democracia.

Israel Getzler no artigo Outubro de 1917: o debate

\footnotetext{
* Professora do Depto. de Ciências Sociais do Centro de Letras e Ciências Humanas da Universidade Estadual de Londrina - Paraná.

A. Gramsci, é sem nenhuma dúvida, um dos pensadores marxistas mais importantes deste periodo. No entanto, não será possível, no âmbito deste trabalho, dar conta de suas discussões sobre a problemática da relação socialismo e democracia, o que envolveria trabalhar inúmeras e polêmicas questões, tais como: a relação entre sociedade civil e sociedade política, bloco histórico, hegemonia, política e cultura, história e revolução, etc..
} 
marxista sobre a revolução Russa ${ }^{2}$ sistematiza os debates que haviam no interior do processo revolucionário e mostra que uma das temáticas mais importantes era a da relação socialismo e democracia.

As vicissitudes do pensamento socialista nos anos da "grande crise" do capitalismo também serão analisadas neste trabalho. Serão abordados os debates sobre planificação, organização corporativa, mediação entre intervenção estatal na economia e governo das massas, etc., no socialismo europeu.

$\mathrm{O}$ corporativismo socialista defendido por $\mathrm{H}$. De Man, por exemplo, no artigo Le corporativisme socialiste contre l'étatisme, publicado em $1934^{3}$ tratava da relação propriedade e controle, do exercício do direito de gestão, etc., a partir das especificidades do Estado naquele momento. Portanto, era preciso redefinir os corpos intermediários do Estado moderno. Assiste-se à defesa da necessidade de mediação entre política econômica e compromisso institucional.

Esta mediação foi feita por alguns países com um projeto político social-democrata. Foi esta possibilidade de combinação do público e do privado de maneira singular que definiu uma forma de gestão social. Mário Telo, no artigo Teoria e política da planificação no socialismo europeu entre Hilferding e Keynes $^{4}$, demonstra como a social-democracia sueca na década de 1930, combinou as convicções enraizadas do socialismo europeu com o aproveitamento crítico do marxismo da $2^{\circ}$ internacional de forma extraordinária.

Os elementos tais como: planificação, transformação do Estado para incorporar a ele novas instituições, socialização igualitária da distribuição, etc., são básicos para compreender os rumos que tomaram a discussão em torno da relação entre socialismo e democracia.

Sem nenhuma dúvida, o movimento socialista, nos primeiros cinqüenta anos deste século, foi muito mais avançado do que após a década de 1950, com uma inspiração teórica mais rica. No entanto, é fundamental compreender as reflexões sobre as condições de edificação do socialismo a partir da segunda metade do século $X X$.

O questionamento da universalidade do modelo soviético levou amplos setores da esquerda ocidental a defenderem a autonomia dos partidos comunistas na escolha de caminhos próprios para se chegar ao socialismo.

As discussões sobre estes caminhos conduziram inevitavelmente ao problema da relação entre socialismo e democracia ${ }^{5}$. Neste sentido, há diversos debates reafirmando a necessidade de encontrar vias para um socialismo democrático.

As críticas ao stalinismo e a todo o modelo soviético ficaram mais contundentes a partir das revoluções abortadas na Hungria e da violenta repressão à Primavera de Praga, em 1968, por exemplo.

A concepção leninista de Estado e de democracia é abundantemente questionada. Passa-se a defender que a opção pela democracia por parte do movimento operário e das camadas médias no sistema capitalista é fundamental porque aponta para a compreensão, por parte destes setores, que só no socialismo pode haver uma democracia mais ampla que no capitalismo.

Mesmo que as discussões não tenham ido muito além do que foram no início do século, acredita-se que é de fundamental importância para o tema socialismo e democracia a análise desenvolvida após a década de 50 sobre a incorporação dos direitos democráticos ao processo de luta pela sociedade socialista. As liberdades formais são reafirmadas como conquistas básicas que nenhuma sociedade socialista poderia negar ou desdenhar 6 .

As reflexões em torno da via democrática para o socialismo serão abordadas para compreender os rumos que têm tomado as discussões sobre o papel do Estado no processo de transformação social, das instituições da democracia representativa e das mudanças nos mecanismos da produção e da distribuição que exigem apoio e consenso dos trabalhadores.

Como mostra Renato Zangheri no artigo Entre a crise do capitalismo e o novo socialismo no ocidente ${ }^{7}$ os processos graduais de mudanças na economia ligamse ao problema da democracia, pois diz respeito a formas de participação dos trabalhadores nas decisões políticas e econômicas, ou seja, há "necessidade de

2 GETZLER,I. Outubro de 1917: O debate marxista sobre a revolução Russa. In HOBSBAWM, E. J.(org) História do marxismo. v.5, Rio de Janeiro, Paz e terra, 1985. p. 25-74.

3 Vide texto de TELO, M. Teoria e política da planificação no socialismo europeu entre Hilferding e Keynes. In. HOBSBAWM, E. J . (org) História do marxismo. v. 8. Rio de Janeiro, Paz e Terra, 1987. p. 135-197

4 lbid.

5 HOBSBAWM, E.J. O eurocomunismo e a longa transição capitalista. Encontros com a Civilização brasileira. V.4. Rio de Janeiro Civilização Brasileira, 1978. p.226-232

6 Sobre estas questões ver as posições de Hobsbawm, Condé, Larsen, Kanapa e Kardelj em:

DOSSIER sobre o Eurocomunismo. Encontros com a civilização brasileira. V.4. Rio de Janeiro, Civilização brasileira, 1978 p.224-258.

7 ZANGHERI, R. Entre a crise do capitalismo e o novo socialismo no ocidente. In HOBSBAWM, E.J.(org). História do Marxismo. V.12, Rio de Janeiro, Paz e Terra, 1989. p.275.

s Ibid.

9 Cesare Luporini diz que tanto em Marx como em todo marxismo deste século há um vazio teórico a respeito do Estado. Ver debate entre diversos teóricos europeus sobre esta questão em:RADICE, L. L. Um socialismo a inventar. São Paulo, Brasiliense, 1982. BOFFA, M. et al. O marxismo e o Estado. Rio deJaneiro, Graal, 1979 
que uma direção econômica renovadora se baseie numa dialética democrática"8.

\section{1 - Socialismo e democracia: um debate vigoroso na primeira metade do século $\mathrm{XX}$}

Faz-se necessário ressaltar que o problema da relação socialismo e democracia é inseparável da relação Estado e sociedade. Neste ponto está grande parte do enigma que cerceia este tema, na medida em que, não há no marxismo a formulação de um estatuto teórico para a questão do Estado ${ }^{9}$. É preciso destacar que a razão desta ausência é fundamentalmente teórica, pois o Estado aparece como uma criação superestrutural e não se deu a ele a devida problematização.

A social-democracia de inspiração marxista, que discutiu abundantemente a relação socialismo e democracia, pensou a teoria democrática como forma de reformar o Estado, por exemplo, mas não fez uma revisão teórica sobre a questão do Estado.

É possível encontrar alguma teorização sobre democracia em Marx? Há quem diga que sim e há quem diga ser impossível extrair de seus escritos qualquer discussão sobre democracia. No entanto, é fundamental voltar um pouco a Marx na questão da relação Estado e sociedade civil para, a partir daí, pensar a problemática do marxismo ${ }^{10}$ com relação à democracia.

Segundo Ruy Fausto, em Crítica da filosofia do direito de Hegel, de 1843, ${ }^{11}$ pode-se encontrar um elogio da democracia em Marx. O seu modelo de democracia seria uma espécie de conciliação entre o indivíduo e o universal. Desta forma, a democracia aparece como realização dessa conciliação em oposição aos estados reais, onde há uma espécie de ruptura entre o indivíduo privado e o cidadão ${ }^{12}$.

Imediatamente, ou seja, em 1844, já é visível um rompimento com essa idéia de democracia. Ruy Fausto afirma que em A questão Judaica e a Crítica da filosofia do direito de Hegel - Introdução, já se detectava um abandono da democracia. Há uma preocupação com os "indivíduos atomizados da sociedade civil, por um lado, e, por outro, o Estado como um universal. Só que no texto de 1843 , essa união se faz dentro dos quadros do Estado representando politicamente a democracia. No texto de 1844, essa união não se fará mais no espaço do Estado, mas contra o Estado"13.

Nas obras posteriores, diz Ruy Fausto, Marx acaba por plantar a semente do reducionismo na questão do Estado e da democracia, ao não trabalhar algo que já havia sido colocado pela tradição hegeliana: a separação entre sociedade civil e sociedade política. Os herdeiros do lado sombrio deste reducionismo tomam o Estado como um mero instrumento de classe, e a democracia como uma "organização chamada a exercer a violência sistemática de uma classe contra outra"14.

No âmbito do marxismo, a social-democracia, no início do século $X X$, merece destaque pela originalidade nas discussões sobre a relação socialismo e democracia, o que foi demonstrado nas suas formulações sobre a importância da democracia para o proletariado, o questionamento do significado da ditadura do proletariado, a não-equalização de democracia e capitalismo, etc. ${ }^{15}$

Kautsky, em A ditadura do proletariado, afirmava que por socialismo moderno não se pode entender apenas a organização coletiva da produção, mas igualmente a organização democrática da sociedade. Desta forma, o socialismo estaria indissoluvelmente ligado à democracia ${ }^{16}$.

Não há, na social-democracia, uma insistência na concepção de destruição do Estado, há sim uma teoria de transformação do Estado a partir do momento em que a classe operária penetra na política. $O$ processo de conversão da classe operária em maioria política é tarefa do partido. Assim, a transformação política leva à ruptura. Kautsky afirma que "se num Estado democrático o proletariado se desenvolve até tornar-se tão numeroso e poderoso para tomar o poder político pela simples aplicação das liberdades dadas, então a 'ditadura capitalista' terá muitas dificuldades para mobilizar os instrumentos de repressão necessários à supressão violenta da democracia"17.

A democracia teria, para Kautsky, grande influência no processo de amadurecimento do proletariado, o que quer dizer "que a revolução não pode

\footnotetext{
10 Adam Przeworski afirma que "Marx considerava a democracia capitalista uma forma basicamente instável de organização da sociedade. Não poderia ser duradoura. (...) Julgava a organização democrática das sociedades capitalistas 'apenas um espasmódico, excepcional estado de coisas[...]impossivel como forma normal de sociedade." PRZEWORSKI,A. Bases materiais do consentimento. In. Capitalismo e social-democracia. São Paulo, Cia de Letras, 1989. p. 161.

11 FAUSTO, R. Marxismo e democracia. Fortaleza, UFC:NEPS, 1990. Série estudos e pesquisas, n. 18.

12 Ibid. p. 39.

13 Ibid.

14 LÊNIN, V. I. El Estado y la revolucion. Buenos Aires, Anteo, 1973. p.101.

15 A exposição de G.D.H. Cole sobre a controvérsia revisionista mostra como em todos os momentos de sua discussão Kautsky não se afastou do marxismo, era sim um dos seus teóricos mais importantes COLE, G.D.H. História del pensamiento socialista. V.III. La segunda internacional 1889-1914. México, Fondo de cultura económica, 1959. p.240-281.

16 KAUTSKY, K. A ditadura do proletariado. São Paulo, Ciências Humanas, 1979 . p.6.

17 Ibid. p. 8

18 WANDENBERG, M. A estratégia política da social-democracia alemã. In HOBSBAWM, E. J. História do marxismo. V.2. Rio de Janeiro, Paz e Terra, 1982, p.228.

19 GETZLER, op. cit, p.57-58.
} 
marxista sobre a revolução Russa ${ }^{2}$ sistematiza os debates que haviam no interior do processo revolucionário e mostra que uma das temáticas mais importantes era a da relação socialismo e democracia.

As vicissitudes do pensamento socialista nos anos da "grande crise" do capitalismo também serão analisadas neste trabalho. Serão abordados os debates sobre planificação, organização corporativa, mediação entre intervenção estatal na economia e governo das massas, etc., no socialismo europeu.

O corporativismo socialista defendido por $\mathrm{H}$. De Man, por exemplo, no artigo Le corporativisme socialiste contre l'étatisme, publicado em $1934^{3}$ tratava da relação propriedade e controle, do exercício do direito de gestão, etc., a partir das especificidades do Estado naquele momento. Portanto, era preciso redefinir os corpos intermediários do Estado moderno. Assiste-se à defesa da necessidade de mediação entre política econômica e compromisso institucional.

Esta mediação foi feita por alguns países com um projeto político social-democrata. Foi esta possibilidade de combinação do público e do privado de maneira singular que definiu uma forma de gestão social. Mário Telo, no artigo Teoria e política da planificação no socialismo europeu entre Hilferding e Keynes ${ }^{4}$, demonstra como a social-democracia sueca na década de 1930, combinou as convicções enraizadas do socialismo europeu com o aproveitamento crítico do marxismo da $2^{\circ}$ internacional de forma extraordinária.

Os elementos tais como: planificação, transformação do Estado para incorporar a ele novas instituições, socialização igualitária da distribuição, etc., são básicos para compreender os rumos que tomaram a discussão em torno da relação entre socialismo e democracia.

Sem nenhuma dúvida, o movimento socialista, nos primeiros cinqüenta anos deste século, foi muito mais avançado do que após a década de 1950, com uma inspiração teórica mais rica. No entanto, é fundamental compreender as reflexões sobre as condições de edificação do socialismo a partir da segunda metade do século $X X$.

O questionamento da universalidade do modelo soviético levou amplos setores da esquerda ocidental a defenderem a autonomia dos partidos comunistas na escolha de caminhos próprios para se chegar ao socialismo.

As discussões sobre estes caminhos conduziram inevitavelmente ao problema da relação entre socialismo e democracia ${ }^{5}$. Neste sentido, há diversos debates reafirmando a necessidade de encontrar vias para um socialismo democrático.

As críticas ao stalinismo e a todo o modelo soviético ficaram mais contundentes a partir das revoluções abortadas na Hungria e da violenta repressão à Primavera de Praga, em 1968, por exemplo.

A concepção leninista de Estado e de democracia é abundantemente questionada. Passa-se a defender que a opção pela democracia por parte do movimento operário e das camadas médias no sistema capitalista é fundamental porque aponta para a compreensão, por parte destes setores, que só no socialismo pode haver uma democracia mais ampla que no capitalismo.

Mesmo que as discussões não tenham ido muito além do que foram no início do século, acredita-se que é de fundamental importância para o tema socialismo e democracia a análise desenvolvida após a década de 50 sobre a incorporação dos direitos democráticos ao processo de luta pela sociedade socialista. As liberdades formais são reafirmadas como conquistas básicas que nenhuma sociedade socialista poderia negar ou desdenhar6.

As reflexões em torno da via democrática para o socialismo serão abordadas para compreender os rumos que têm tomado as discussões sobre o papel do Estado no processo de transformação social, das instituições da democracia representativa e das mudanças nos mecanismos da produção e da distribuição que exigem apoio e consenso dos trabalhadores.

Como mostra Renato Zangheri no artigo Entre a crise do capitalismo e o novo socialismo no ocidente ${ }^{7}$, os processos graduais de mudanças na economia ligamse ao problema da democracia, pois diz respeito a formas de participação dos trabalhadores nas decisões políticas e econômicas, ou seja, há "necessidade de

2 GETZLER,I. Outubro de 1917: O debate marxista sobre a revolução Russa. In HOBSBAWM, E. J.(org) História do marxismo. v.5, Rio de Janeiro, Paz e terra, 1985. p. 25-74.

3 Vide texto de TELO, M. Teoria e política da planificação no socialismo europeu entre Hilferding e Keynes. In. HOBSBAWM, E. J . (org). História do marxismo. v. 8. Rio de Janeiro, Paz e Terra, 1987. p. 135-197.

4 Ibid.

5 HOBSBAWM, E.J. O eurocomunismo e a longa transição capitalista. Encontros com a Civilização brasileira. V.4. Rio de Janeiro Civilização Brasileira, 1978. p.226-232.

6 Sobre estas questões ver as posições de Hobsbawm, Condé, Larsen, Kanapa e Kardelj em: DOSSIER sobre o Eurocomunismo. Encontros com a civilização brasileira. V.4. Rio de Janeiro, Civilização brasileira, 1978, p.224-258.

7 ZANGHERI, R. Entre a crise do capitalismo e o novo socialismo no ocidente. In HOBSBAWM, E.J.(org). História do Marxismo. V.12, Rio de Janeiro, Paz e Terra, 1989. p.275.

8 Ibid.

9 Cesare Luporini diz que tanto em Marx como em todo marxismo deste século há um vazio teórico a respeito do Estado. Ver debate entre diversos teóricos europeus sobre esta questão em:RADICE, L. L. Um socialismo a inventar. São Paulo, Brasiliense, 1982. BOFFA, M. et al. O marxismo e o Estado. Rio deJaneiro, Graal, 1979.

Semina Ci. Sociais/Hum., v. 17, n. 3, p. 274-285 
ser realizada num momento estabelecido por determinadas forças políticas ou por um indivíduo, mas deve ser realizada no momento justo, quando estejam maduras as condições indispensáveis"18.

A defesa da democracia tinha em vista a necessidade de organização do proletariado nas condições específicas de alguns países onde estes já possuíam alguns direitos políticos. Desta forma, a busca da relação entre socialismo e democracia refletia a procura de condições de passagem ao socialismo. Eram necessários os seguintes pré-requisitos para a implantação do socialismo, segundo Kaustky: " um proletariado forte, em vias de desenvolvimento e amadurecimento político, (...) desenvolvimento de uma indústria em ampla escala, uma taxa de democracia capaz de permitir ao proletariado a organização e o amadurecimento"19.

Para Kautsky, enquanto luta de massa, a luta de classe do proletariado exige a democracia. Mesmo que não se trate exatamente da democracia absoluta ou pura, é, apesar de tudo, necessário ter democracia suficiente para organizar as massas e informá-las regularmente ${ }^{20}$.

No entanto, a democracia tanto permite o processo de amadurecimento do proletariado como permite reconhecer se a maturidade foi ou não alcançada. Em A ditadura do proletariado, Kautsky afirma que a democracia convida os cidadãos a pensarem e a discutirem os problemas do Estado, e isto acaba por se converter numa prática cotidiana de autoadministração.

Neste sentido, Kautsky argumentava que um regime democrático só usará a força para defender a democracia e não para aniquilá-la. A própria ditadura do proletariado não é outra coisa senão o reinado do proletariado à base de democracia.

Para Kautsky, quanto mais um Estado é democrático, mais o proletariado é organizado e mais próximo se está do socialismo. Assim, o futuro do proletariado não reside na ditadura, mas sim na democracia. No caso da revolução russa, as conquistas seriam salvas se a ditadura fosse substituída imediatamente pela democracia.

Lênin, em A revolução proletária e o renegado Kautsky, rejeitava essas argumentações, dizendo que elas não faziam mais que repisar as idéias liberais e não passavam de "tagarelice para embrulhar os trabalhadores "21. Se a democracia para Lênin era uma forma de Estado e sendo este um instrumento de dominação, a democracia era democracia dos exploradores $^{22}$.

Lênin, respondendo ao livro de Kautsky A ditadura do proletariado, fazia uma discussão sobre o parlamento burguês e a dissolução da assembléia constituinte, e afirmava que quanto mais desenvolvida fosse a democracia, mais o parlamento dependia da bolsa e dos banqueiros. A extinção do Estado implicava na extinção da democracia ${ }^{23}$, uma vez que para Lênin as técnicas de instituições representativas eram, na verdade, restrições que excluíam os pobres da política.

Trotsky, em Terrorismo e comunismo, no capítulo "a democracia," também refutava totalmente as discussões de Kautsky ${ }^{24}$, afirmando que este último não conhecia outro caminho a não ser a democracia, mas que nada garantia que esta levaria a classe operária à emancipação. Isto porque, assinala Trotsky, o Estado democrático burguês não se limita a conceder aos trabalhadores melhores condições de desenvolvimento, mas também incumbe-se de implantar numa aristocracia operária, o oportunismo ${ }^{25}$.

Assim como Lênin, Trotsky rechaça a democracia em nome do poder proletário centralizado, pois acreditar na necessária relação entre democracia e socialismo, não é, diz Trotsky, nada mais que alimentar pobres utopias reacionárias.

Voltando à social-democracia, é necessário ressaltar a problemática da socialização ${ }^{26}$, pois esta remete diretamente a um projeto político que tinha como espinha dorsal a relação socialismo/democracia e revolução/reforma.

Para Bernstein, "o problema central na passagem do capitalismo ao socialismo não é tanto a conquista do poder político pelo proletariado, mas sim a

20 KAUTSKY, op. cit. p. 15.

21 LÊNIN, V. I. A revolução proletária e o renegado Kautsky. São Paulo, Ciências Humanas, 1979. p.105.

22 Ibid. p. 113.

23 Id, El Estado y la revolucion. Buenos Aires, Anteo, 1973. p.101.

${ }^{24} \mathrm{O}$ texto de Trotsky também denominado "El anti-Kautsky" foi escrito em resposta ao texto de Kautsky chamado Terrorismo y comunismo, escrito em 1919, que era parte de uma série de brochuras que Kautsky escreveu entre 1918 a 1921 fazendo "ecoar todas as desilusões e a indignação crescente a que o levava seu anti-bolchevismo cada vez mais violento". GETZLER, op. cit. p. 57

25 TROTSKY, L. Terrorismo y comunismo. Madrid, Júcar, 1977 . p.175.

${ }^{26}$ Sobre o debate em torno da socialização, o artigo de E.Weissel é fundamental por discutir os desafios enfrentados pela socialdemocracia na formulação de um projeto concreto que levasse em conta as condições políticas e econômicas dos anos 20 . "E essa discussão em torno de um projeto que fosse realista e realizável, da qual tomassem parte todos os que queriam dar uma contribuição à realização do socialismo, passou à história como debate sobre a socialização".

WEISSEL, E. A internacional socialista e o debate sobre a socialização. In HOBSBAWM, E. História do marxismo. V.5. Rio de Janeiro, Paz e Terra, 1985. p.229-230.

27 WALDENBERG, op. cit. p.241.

28 RADICE, G. Socialismo democrático. Rio de Janeiro, Zahår, 1967. p.31

29 BERNSTEIN, E. Socialismo evolucionário. Rio de Janeiro, Zahar, 1964.

30 Ibid. 
socialização dos meios de produção e a organização da produção de acordo com os princípios do socialismo"27.

A preocupação era com as condições de socialização da propriedade capitalista dos meios de produção. A transformação socialista não podia estagnar o processo produtivo. Daí a idéia de gradualismo e de evolução, que é pensada tanto nas relações econômicas quanto no sistema político.

Bersntein, juntamente com Bebel, Hansson, Blum, Attlee, discutiam as condições e possibilidades do avanço parlamentar do socialismo na Europa ${ }^{28}$ defendendo a idéia de que o crescente poder das classes operárias, através de seus representantes sindicalistas e parlamentares, colocava a possibilidade de emergência de uma sociedade sem classes de maneira gradual e também constitucional ${ }^{29}$.

Bernstein é o que melhor formulou uma argumentação teórica sobre a passagem do capitalismo ao socialismo numa perspectiva gradualista. Para ele, o capitalismo evoluiria no sentido do socialismo, não num processo repentino, mas que duraria décadas. A democracia ganhava, então, um papel fundamental enquanto fim e enquanto meio. "É o meio de luta para o socialismo e é a forma que o socialismo tomará, uma vez realizado" 30 .

A relação socialismo e democracia não era tomada como algo abstrato ou ideal pelos socialdemocratas. Seus pressupostos assentavam-se no fato de que as instituições democráticas tinham sido fortalecidas a partir de conquistas básicas dos movimentos trabalhistas. E sob pressão dos trabalhadores é que teriam ocorrido as limitações do poder e as mudanças feitas de forma constitucional.

A preocupação do partido social-democrata sueco com a questão da socialização e com as conquistas com relação aos direitos de cidadania, mostra que havia um diálogo dos grandes teóricos do marxismo com as questões que se colocavam a nível do movimento de modificação na relação política e econômica em alguns países europeus. Havia, sem dúvida, uma interação entre o movimento político daquele momento e as teorizações dos clássicos do marxismo a respeito das condições de passagem ao socialismo.

Bernstein considerava realista pensar a transformação da sociedade a partir da previsão de uma evolução "em sentido democrático das formas do
Estado, que perderia o seu caráter classista, de supremacia de uma classe sobre outra." ${ }^{31}$ A socialdemocracia deveria lutar por obter o apoio dos setores médios, isto porque, era de fundamental importância conseguir o apoio da maioria da sociedade. Mas antes disto, a social-democracia "deveria tentar formar uma coalização de governo com uma parte dos partidos burgueses, na medida em que é verdade que, na história, nenhuma classe jamais alcançou imediatamente a totalidade do poder estatal"32.

As transformações seriam, segundo Bernstein, progressivas. Conforme seu livro, O socialismo evolucionário, haveria uma evolução do sistema estatal no sentido de um sistema democrático parlamentar. Uma forte posição no parlamento possibilitaria uma luta incessante por reformas econômicas e políticas que caminhariam na direção da transformação social.

Bernstein ressaltava que "a idéia de democracia inclui, na acepção moderna, uma noção de justiça e igualdade de direitos para todos os membros da comunidade (...) neste princípio, o governo da maioria (...) acha seus limites" ${ }^{33}$. Ao falar de democracia moderna, Bernstein está se referindo à justiça e à igualdade de direitos e estes elementos remetem à democracia representativa, mas vão além dessa.

As discussões de Rosa Luxemburgo também tiveram um papel importante, no início do século, nos debates sobre a relação entre socialismo e democracia. Sem discutir aqui todo o processo de seu afastamento e ruptura com a social-democracia alemã, destaque-se que ela desempenhou também um importante papel nos debates sobre os caminhos que tomava a revolução russa. Suas posições, como diz Getzler, eram ao mesmo tempo de entusiasmo e espírito crítico e sua acusação mais violenta aos bolcheviques refere-se à supressão da liberdade e da democracia ${ }^{34}$

Rosa Luxemburgo condenou, em A revolução Russa, a dissolução da Assembléia Constituinte. Para ela, este era um passo no sentido de um governo autoritário ${ }^{35}$. O fim da liberdade de imprensa e do direito de reunião também atentava contra os direitos em geral e levaria a um tipo de governo autocrático. Ela questionava a concepção de ditadura do proletariado de Lênin e Trotsky, afirmando que esta " significava democracia mais ampla e ilimitada'"36.

A liberdade política devia ser o fundamento do socialismo, uma vez que ela garantia a participação das massas no processo revolucionário. Os mecanismos

\footnotetext{
${ }^{31}$ WALDENBERG, op .cit. p. 242.

3 Ibid. p. 242.

33 BERNSTEIN, op. cit.

${ }^{34}$ GETZLER, I. op. cit. p. 62

35 LUXEMBURGO, R. La revolución Russa. In. Obras escogidas I. México, Era, 1978. p.214-252.

36 GETZLER, op. cit. p. 62.

37 WALDENBERG, op .cit. p. 244

${ }^{38}$ NEGT, O. Rosa Luxemburg e a renovação do marxismo. In HOBSBAWM, E. J. (org). História do marxismo. V.3. Rio de Janeiro, Paz e Terra, 1984. p.11-51

э9 lbid. p. 30 .
} 
de formação da consciência de classe e da vontade revolucionária estão relacionados a estas liberdades políticas, dizia R.Luxemburgo.

Waldenberg afirma que, para Rosa de Luxemburgo, a luta pelo poder era um processo revolucionário de longa duração, durante o qual o proletariado poderia, até a conquista definitiva, ganhar e perder o poder ${ }^{37}$.

Rosa Luxemburgo desenvolveu a idéia de democracia de base como produto da greve de massa que deveria estar fundamentada nos conselhos de operários. A democracia conselhista tinha que ser 0 elemento político-organizativo básico do socialismo, uma vez que o mero socialismo de governo ${ }^{38}$ tinha que ser combatido.

Há ainda uma observação fundamental de Negt de que "para Rosa Luxemburgo, o caráter fundamental, imutavelmente democrático, da estrutura organizativa das organizações proletárias(...), não é só um postulado que deriva da idéia do objetivo final, da libertação dos homens da opressão e da exploração, mas tem também o seu fundamento metodológico: toda organização ou movimento proletário não democrático entra em contradição com a dialética materialista; e, ainda que a conquista revolucionária do poder devesse ter êxito, levaria, de uma ou de outra forma, à falência" ${ }^{39}$.

A partir da democracia conselhista, Rosa Luxemburgo defende a conquista do poder de forma particular, o processo de conquista não se daria contra o Estado, mas dentro do Estado. "A conquista do poder não se realiza somente através de um golpe, mas progressivamente, penetrando como uma cunha no Estado burguês até ocupar todas as suas posições e defendendo-as com unhas e dentes(...). Devemos lutar passo a passo, corpo a corpo, em todo Estado, em toda cidade, em toda vila, em toda comuna, para transferir aos conselhos dos operários e soldados todos os instrumentos do poder estatal que devem ser, pedaço por pedaço, arrancados à burguesia"40.

A construção da democracia socialista, segundo Luxemburgo, levaria um longo período de tempo, porque exigiria a eliminação de qualquer domínio político enquanto tal. $E$ isto não se faz por decretos, mas através de mediações históricas concretas.

A democracia de base ou conselhista, defendida por Rosa Luxemburgo, aponta para uma forma específica de conceber a relação socialismo e democracia. Objetivou-se, aqui, apontar justamente para essa especificidade, e, ao mesmo tempo, demonstrar que para esta militante e teórica do marxismo, o destino da democracia estava indubitavelmente ligado ao movimento socialista.

No livro Reforma o revolución, Luxemburgo faz uma observação de suma importância: o movimento operário socialista é o único suporte da democracia. "Quem quiser fortalecer a democracia deveria fortalecer e não debilitar o movimento socialista. Quem renuncia à luta pelo socialismo, renuncia tanto ao movimento operário como à democracia"41. O proletariado, chegando ao poder, tem como missão histórica criar uma democracia socialista e não destruir toda forma de democracia ${ }^{42}$.

$O$ debate político, que floresceu no início do século $X X$, contou também com a contribuição dos teóricos do austromarxismo. Expoentes do socialismo marxista não-leninista desenvolveram alguns pontos básicos da relação socialismo e democracia. Serão destacados aqui os escritos de Max Adler e de Otto Bauer sobre esta questão específica.

Otto Bauer tinha uma visão eminentemente crítica da condução do processo revolucionário russo. Criticava não apenas os bolcheviques que "haviam depositado toda confiança no 'supremo poder das metralhadoras'"43, mas também os Mencheviques pelo "minimalismo tímido e o coalizacionismo impossível"44.

A insistência na necessidade de que a revolução russa abrisse uma perspectiva democrática ganhou relevo nas discussões de Bauer, concordava com a afirmação de Martov de que a democracia era indispensável no processo de emancipação da classe operária. A possibilidade de um governo democrático na Rússia revolucionária era apontada como um fato de primeira grandeza para o futuro do proletariado na Europa, conforme carta de Bauer a Kautsky, em setembro de 1917.

Em análise sobre as condições da Rússia, em 1917, Bauer enfatizava que a revolução devia estabelecer as liberdades políticas, a socialização da propriedade da terra e a jornada de 8 horas. A revolução, no entanto, não devia desembocar na ditadura do proletariado ${ }^{45}$. É fundamentalmente importante destacar que Bauer era muito cuidadoso com as críticas que fazia à revolução russa, uma vez que a crítica mal feita poderia desanimar os trabalhadores europeus.

\footnotetext{
40 LUXEMBURGO, R. Discurso sobre o programa. Escritos políticos.

V.2. México, Era, 1978 . p. $629-630$

41 Id, Reforma o revolución. México, Grijalbo, 1967. p. 84-85.

42 Id, Escritos políticos II. V.2. México, Era, 1978. p. 593.

43 GETZLER, op. cit. p.64.

44 Ibid.

45 Ibid, p. 65

46 lbid, p. 67.

47 Ibid, p. 67

48 Ibid, p. 68.

49 ADLER, M. Democrazia política e democrazia sociale. Roma, Runniti, 1945.

50 Id, Democrazia e consigli operai. Roma, Runniti, 1970.
} 
abordadas as discussões sobre as vicissitudes do Estado e da democracia recaindo, portanto, a ênfase em questões tais como: planificação e reformas, corporativismo, direito de gestão e compromisso institucional.

Delinear as vicissitudes do Estado e da democracia não é uma tarefa fácil. Convém esclarecer, de início, que não se fará aqui um traçado que vai da gênese e formação do Estado até a crise do Welfare state, assim como não será possível fazer uma abordagem ampla e profunda da democracia.

Serão apontadas algumas questões sobre a forma de articulação do âmbito sócio-econômico com o político-institucional, após a década de 1930, naqueles aspectos que possibilitarão extrair elementos para compreender os caminhos tomados pela problemática socialismo e democracia.

A complexidade do Estado como categoria e como problema teórico foi, sem dúvida, o grande dilema das discussões que tentavam, nos anos da "grande crise," decifrar as mudanças de forma e de funções do Estado. Mesmo não sendo possível trabalhar exaustivamente com os debates em torno do corporativismo, da democracia coletiva, do pluralismo e da democracia de compromisso, considera-se fundamental a abordagem de Giacomo Marramao ${ }^{54}$ sobre essas questões, porque contém os elementos básicos para compreensão do tema que está sendo analisado.

As discussões de Marramao, citadas no último parágrafo, apontam para os novos problemas que se colocavam para o movimento socialista na década de 30. As dificuldades em articular socialismo e democracia pareciam enormes. Há, nos anos da "grande crise," um amplo questionamento sobre os caminhos da própria democracia. Mário Telo assinala que o socialismo europeu, depois da crise de 1929 e da derrota da socialdemocracia alemã com o advento do nazismo, conheceu uma fase de radicalização ${ }^{55}$.

Mas, mesmo nessa fase de maior radicalização, um dos caminhos que continua sendo ressaltado é o da possibilidade de que um governo democrático evoluísse para uma transição ao socialismo. Merece destaque também a interpretação ${ }^{56}$ da transformação socialista a partir da progressiva intervenção pública na economia.

Segundo Mario Telo $^{57}$ assistia-se, na década de 1930, não só a uma crise do sistema capitalista, mas também do pensamento socialista. "Ainda com lucidez

\footnotetext{
58 Ibid, p. 135.

50 As posições de De Man, G. Lefranc, etc. foram discutidas em: TELO, op. cit. p. 171-184.

60 Sobre o movimento socialista nos anos 30 , ver:

COLE, G. D. H. História del pensamiento socialista. V.5, México, Fondo de cultura, económica, 1959.

61 Sobre essas posições no socialismo europeu ver: TELO, op. cit, p.137.

62 Ibid, p.139.

63 Ibid, p. 143

64 Ibid, p. 171

6 Ibid, p. 188.
}

desigual, emerge em componentes não secundários do socialismo europeu uma compreensão do alcance das derrotas sofridas e dos processos de transformação social e política em curso. A exigência do início de uma 'nova fase da história do movimento operário,' indicada por Bauer em 1932, expressa-se, pois, num complexo entrelaçamento de análise social, revisão ideológica e teórica, investigação sobre os termos da redefinição do papel das organizações operárias no sistema político"58.

As reflexões sobre a relação socialismo e democracia lutavam, neste momento, com as interrogações acerca da possibilidade de organização das massas para exigir o fortalecimento da própria democracia numa época de crise, com graves conseqüências sociais.

Os sindicatos europeus defendiam a necessidade de vencer a impotência do movimento sindical naqueles anos de crise. Esses e outros dados confirmam que os problemas colocados pela crise do capitalismo faziam com que a discussão sobre a construção do socialismo levasse em conta os elementos oriundos dessas condições.

Havia interpretações distintas das perspectivas do socialismo diante da crise ${ }^{59}$ dos anos $30^{60}$. Existia, inclusive, a idéia de que a crise devia ser aproveitada como o momento propício para se acelerar a transição ao socialismo. Insistia-se na possibilidade de trazer o objetivo do socialismo para aquele momento ${ }^{61}$.

Na década de 1930 há, no socialismo europeu, uma ampla defesa da planificação, sem entrar em detalhes sobre a inspiração política diversa dos socialistas adeptos de uma política planificada, é possível afirmar que esta corrente era um componente do movimento social-democrata. Dentre as preocupações básicas, estava a de produzir planos nacionais para o emprego ou programas de governo.

Neste aspecto encontram-se, na década de 1930, as preocupações com as etapas intermediárias e transitórias no processo de transformação social. É fundamental destacar esta mudança, uma vez que "uma afirmação imediata do objetivo da socialização, destituída de conotações nacionais específicas e distante da formulação de prioridades, alianças, formas transitórias, etc., tinha caracterizado o conjunto do movimento revolucionário do pós-guerra."62 A forma específica, que assume o pensamento socialista na década de 1930 , dados os novos problemas que o socialismo europeu tinha que enfrentar, fica evidente na defesa de que, mesmo ante aquela situação de crise, 
era possivel preservar uma relação harmoniosa entre capitalismo organizado, (conforme teorizações de Hilferding), formas políticas democráticas e avanço para o socialismo ${ }^{63}$.

O movimento socialista, na década de 30 , adepto da planificação, problematiza duas questões de suma importância: a direção da economia e a concretização da perspectiva socialista. As duas questões aparecem interligadas nos debates. Trava-se uma série de discussões sobre mudança política e transformação social.

O movimento planista, que contava na década de 1930 com importantes teóricos (De Man, Cole,etc.), fez uma apurada reflexão sobre as novas condições sociais vigentes e as possibilidades de pensar a sociedade socialista. "A análise da 'crise estrutural' do capitalismo torna-se a base para uma redefinição da relação entre interesses materiais e movimento histórico, para uma transformação do socialismo."64 Varga foi também um importante teórico daquele momento que polemizava com De Man e outros sobre a questão do controle político da economia e a questão institucional relacionadas com as dificuldades de controles e programações antes da conquista do poder político.

De Man, ao defender o corporativismo socialista, discute as formas de transformações do Estado para incorporar novas instituições. Isto pode ser considerado como uma tentativa de redefinição dos corpos intermediários no Estado como uma forma de resposta às condições históricas vigentes, que exigiam formas de mediação entre política econômica e compromisso institucional.

O governo social-democrata sueco, na década de 1930, conseguiu traduzir em política de governo, desenvolvimento econômico combinado com o compromisso institucional, o que levou a uma gestão social da riqueza. Isto foi possível dado o processo de transformação do partido social-democrata num partido de massa que passa a lutar brilhantemente pela democracia política plena. Este processo político levou à possibilidade de repensar a relação entre o movimento operário organizado, o governo e o Estado.

Segundo Mário Telo, "a nova posição do Partido Social-Democrata nasce de uma opção básica em favor de um processo de aproximação ao socialismo por etapas intermediárias, cujo alcance e limites são determinados conscientemente" 65 .

A busca de reformas institucionais, combinada com a constante preocupação com o que G. Myrdal chamou de "socialização igualitária da distribuição" transformou a Suécia no exemplo mais evidente de que a única possibilidade de se conseguir reformas sociais e econômicas ao mesmo tempo é o fortalecimento das instituições democráticas.

"A social-democracia baseou-se em dois argumentos. Primeiro era o de que os trabalhadores precisam de recursos sociais, saúde e educação para participar efetivamente como cidadãos socialistas. O segundo argumento era o de que a política social não é só emancipadora, é também uma pré-condição da eficiência econômica"66.

A social democracia, uma das matrizes do Welfare State ${ }^{67}$, empenhou-se em defender que o caminho para a realização dos ideais socialistas era a mobilização no sistema parlamentar, o que levaria não só a uma maior igualdade, mas também ao socialismo.

Ressalte-se que no debate contemporâneo sobre - Wélfare state, uma das questões colocadas é a possibilidade destes Estados do bem-estar se transformarem em socialistas ${ }^{68}$. É o que EspingAndersen pergunta no início de seu artigo: "O welfare state pode transformar fundamentalmente a sociedade capitalista?"69

O debate sobre a relação socialismo e democracia que se desenvolveu na Europa, após a

${ }^{6}$ ESPING-ANDERSEN,G. As três economias políticas do welfare state. In Lua Nova, ํo 24, CEDEC, São Paulo, Marco Zero, p. 85-116, Setembro de 1991.

67 Sobre as variações do Welfare State ver: ESPING-ANDERSEN, op. cit. Outras análises sobre o Estado de bem-estar social podem ser encontradas em: KING, D. S. O estado e as estruturas sociais de bem-estar em democracias industriais avançadas. Novos Estudos, no 22, São Paulo, Cebrap, Out.1988. p. 52-76. PRZEWORSKI, A. e WALLERSTEIN, M. O capitalismo democrático na encruzilhada. Novos Estudos, ํㅡ 22, São Paulo, Cebrap, Out. 1988. p. 29-44.

$\circledast$ Sobre esta questão ver:

PRZEWORSKI, A. Capitalismo e social-democracia. São Paulo, Cia das letras, 1989.

• ESPING-ANDERSEN, op. cit. p. 85.

70 HOBSBAWM, E. O eurocomunismo e a longa transição capitalista. Encontros com a civilização brasileira, n 4, Rio de Janeiro, Civilização Brasileira, Out. 1978. p. 226-232.

71 Sobre essas modificações ver os sequintes textos:

BRUS, W. O funcionamento de uma economia socialista. In HOBSBAWM, E. (org) História do marxismo. V.11. O marxismo hoje, ํo parte. Rio de Janeiro, Paz e terra, 1983, p. 247-279.

ADLER, A. Política e ideologia na experiência soviética. In Ibid. p. 133-161.

72 As tendências, dinâmicas e contradições do capitalismo desenvolvido estão trabalhadas no texto:

ALTVATER, E. A teoria do capitalismo monopolista de Estado e as novas formas de socialização capitalista. In HOBSBAWM, E. (org). História do marxismo. V. 12. Rio de Janeiro, Paz e Terra, 1989. p. 283-340.

73 ADLER, op. cit. p. 134 et seq.

74 Sobre o movimento na Tchecoslováquia ver: LONGO, L. Relatório sobre a tchecoslováquia, DELLA VOLPE, G. Crise Tcheca e teoria política e HAVEMANN, R. O caminho de Praga . In Encontros com a civilização brasileira. № 15, Rio de Janeiro, Civilização Brasileira, 1979, p. 132-158.

75 SIQUEIRA, M. T. O. Introdução ao dossier sobre o eurocomunismo. Encontros com a civilização brasileira, no 4, Rio de Janeiro, 1978. p. 225.

Semina Ci. Sociais/Hum., v. 17, n. 3, p. 274-28 
década de 1950, só pode ser compreendido tomando como ponto de partida a estruturação do Estado de bemestar social, onde há um "quadro institucional (...) aceito e interiorizado pela grande maioria do povo e da classe operária"70.

\section{3 - Socialismo e democracia após a década de 1950}

As modificações gestadas nas sociedades socialistas $^{71}$ e capitalistas ${ }^{72}$ após a década de 50 trouxeram novos elementos para o debate em torno da relação socialismo e democracia. A União Soviética transplantou seu modelo para todos os países de direção comunista como um modelo de validade universal.

Concomitantemente a esse processo, ocorre uma reflexão profunda, por parte do movimento socialista dos paises ocidentais, sobre a validade universal do modelo soviético tanto nos seus aspectos econômicos como políticos. A difusão do relatório de Khruschev no Congresso do PCUS em 1956 ${ }^{73}$, contribuiu enormemente para se repensar as condições de edificação do socialismo em sociedades capitalistas avançadas.

Como demonstra A. Adler no artigo Política e ideologia na experiência soviética, a partir da difusão desse relatório em 1956, ficou evidenciada a imagem de uma repressão desapiedada e generalizada. Isto contribuiu, sem nenhuma dúvida, para o questionamento do modelo soviético pelos expoentes do movimento socialista no ocidente.

Evidentemente, o esvaziamento dos partidos comunistas do ocidente não se deve apenas ao último fato citado, mas também às revoluções abortadas da Hungria, da Tchecoslováquia, etc.. Com o massacre da URSS a esta última, chegou-se ao auge do descontentamento e desesperança ${ }^{74} \mathrm{com}$ o modelo soviético.

Alguns países comunistas tentavam romper com - círculo fechado por Stalin através da luta por um processo de democratização que foi sufocådo violentamente. Isto levou a uma certa desmistificação da URSS. Assiste-se a uma reestruturação dos partidos comunistas ocidentais e um esvaziamento de seus quadros intelectuais.

"Nesse sentido, os partidos comunistas ocidentais viram como objetivo principal conceber um Estado socialista que oferecesse garantias para um desenvolvimento democrático pleno. Esta concepção, na medida em que se desenvolveu, orientou-se por um pluripartidarismo possível também no socialismo"75.

Não é só o pluripartidarismo que passa a ser enfocado, mas todas as liberdades e direitos já conquistados são pensados como fundamentais para o socialismo. Questiona-se o conceito de ditadura do proletariado. A transformação social pacífica ganha relevo e é demonstrada como a possibilidade de consolidação e ampliação da democracia até então conquistada pela classe trabalhadora.

$\mathrm{Na}$ segunda metade do século $X X$, especialmente a partir da década de 60 , retomaram-se muitas questões que já haviam sido colocadas no início do século: a relação socialismo e democracia era uma delas. Togliatti, numa conferência em 1947, já dava impulso a essa questão afirmando que era preciso desenvolver a democracia até o seu limite extremo, que era precisamente o socialismo ${ }^{76}$.

O novo socialismo no ocidente ${ }^{77}$ tinha como objetivo básico a busca de novos caminhos para a edificação do socialismo. $E$ isto ocorria tendo em vista tanto os acontecimentos nas sociedades socialistas quanto nas capitalistas, ou seja, tinha a ver com as condições concretas, com as forças sociais presentes nestes sistemas num dado momento.

A retomada de caminhos, já trilhados pelos social-democratas no início do século, como o da democracia para a transição ao socialismo, torna-se uma necessidade. Onde o desenvolvimento do Estado de bem-estar social trouxe para a arena política a real correlação das forças sociais, através de uma gestão democrática, não era mais possível ignorar ou desdenhar essas conquistas ao falar na construção do socialismo.

No início da década de 60, Togliatti escreveu alguns artigos e também pronunciou conferências cujo tema básico era a relação socialismo e democracia. $O$ pano de fundo era, no entanto, a questão do "acesso ao socialismo nas condições das sociedades capitalistas desenvolvidas"78.

As reformas são ressaltadas por Togliatti7 ${ }^{79}$ como formas de modificações na própria estrutura capitalista, na medida em que, nas sociedades desenvolvidas, as classes trabalhadoras, devido ao fortalecimento das instituições democráticas, são capazes de pressionar por reformas cada vez mais profundas.

\footnotetext{
76 TOGLIATTI, P. Socialismo e democracia. Rio de Janeiro, Ilha, 1980. p. 63-72.

77 ZANGHERI, R. Entre a crise do capitalismo e o novo socialismo no ocidente. In HOBSBAWM, E. (org). História do marxismo. V. 12, Rio de Janeiro, Paz e Terra, 1989. p. 221-280.

78 Ibid, p. 222.

79 TOGLIATTI, P. Capitalismo e reformas de estrutura. In. Socialismo e democracia. Rio de Janeiro, Ilha, 1980.

$\$$ ZANGHIERI, op. cit. p. 226-227.

81 Pierre Birnbaum afirma que "a estratégia eurocomunista, que repousa na aceitação da democracia representativa (sufrágio universal, alternância multipartidária, liberdade de imprensa, etc.), aproxima-se consideravelmente da estratégia seguida pela social-democracia alemã sob o impulso de Kautsky".

BIRNBAUM, P. Le peuple et les gros - Historie d'un mythe.Paris, Grasset, 1979. p. 148.

Sobre o Eurocomunismo, ver também: BUCI-GLUCKSMAN, C. Eurocommunisme, transition et pratique politique. In Critique des pratiques politiques. Paris, Galilée, 1978. KRIEGEL, A. Un autre communisme? Paris, Hachette, 1977.
}

Semina Ci. Sociais/Hum., v. 17, n. 3, p. 274-28 
As discussões que se desenvolveram após a década de 1950 sobre a relação socialismo e democracia não eram exatamente as mesmas do início do século, elas tinham as suas especificidades, dadas as próprias condições históricas.

As teorizações de Togliatti sobre as estratégias democráticas para a edificação do socialismo levava em conta as contradições específicas do capitalismo contemporâneo, portanto, colocava-se a problemática do Estado nas sociedades atuais. Como mostra Renato Zangheri, o aumento da intervenção do Estado na vida econômica tinha, para Togliatti, de ser acompanhado por uma ampliação do processo democrático ${ }^{80}$, uma vez que isto garantiria um maior acesso dos trabalhadores à gestão do poder.

Togliatti estava preocupado com os elementos constituintes do processo de luta pela criação de um caminho autônomo na construção do socialismo no ocidente. E o que se convencionou chamar eurocomunismo foi fortemente influenciado por Togliatti, mas não só por ele como já foi demonstrado ${ }^{81}$ anteriormente.

Para Eric Hobsbawm, o que se convencionou chamar eurocomunismo lida com dois argumentos básicos que poderiam ser resumidos da seguinte forma: os países da comunidade comum européia têm em comum determinados problemas e possuem uma estrutura burguesa desenvolvida, o que exige a elaboração de estratégias políticas, econômicas, sociais, institucionais, etc. específicas ${ }^{82}$.

Ressalte-se que a busca de consubstancialidade entre socialismo e democracia encontra nessas condições um terreno fértil para se desenvolver. No entanto, a discussão sobre socialismo e democracia não é produto apenas deste momento histórico, como foi demonstrado nos dois primeiros itens deste trabalho.

A crise do capitalismo, do início da década de 1970 , foi também um componente importante dos debates sobre a via democrática ${ }^{83}$ de transformação da sociedade. O movimento socialista, ao fazer uma reflexão sobre a crise, estava constantemente lidando com questões que remetem à problemática da transformação, das reformas, das instituições democráticas, etc.

Em um "simpósio do Instituto Gramsci, realizado em 1965, foram abordados os aspectos europeus das novas tendências do capitalismo e as exigências de vinculação internacional da luta pelas reformas e pelo socialismo" 84
As reformas de estruturas eram vistas como instrumentos essenciais de mudanças na sociedade capitalista porque possibilitavam um alargamento do espaço público, e as decisões tanto no campo econômico quanto no campo político, passariam a ser controladas pela coletividade.

Há diversas interpretações sobre a possibilidade, nas condições atuais, de universalização democrática da vida social nos países capitalistas desenvolvidos. Os escritos de Habermas e C. Offe são exemplos dessa discussão. $O$ artigo $O$ surgimento do antivalor, de Francisco de Oliveira, faz parte deste debate, numa interpretação distinta dos dois autores supracitados.

Habermas tem uma posição que pode ser resumida a grosso modo da seguinte forma: na "sociedade capitalista desenvolvida os poderes estabelecidos dependem cada vez menos do trabalho e da disposição de cooperação dos empobrecidos e privados de direitos para sua própria reprodução". Desta forma, torna-se absolutamente "difícil a tarefa de viabilizar a universalização democrática das posições de interesses" 85 .

No artigo $\mathrm{O}$ surgimento do antivalor, Francisco de Oliveira, analisando a crise do capitalismo contemporâneo a partir da mercadoria força de trabalho, afirma que houve uma publicização da luta de classe, o que não quer dizer que ocorreu o desaparecimento do sujeito histórico, mas sim uma redefinição do mesmo. O sujeito coletivo passa a ser o sujeito da transformação.

Na medida em que o sistema capitalista não consegue mais se financiar com o próprio lucro, assistese a um constante avanço sobre a riqueza pública e este processo depende da correlação das forças sociais. A ampliação da esfera pública exige uma ampliação da democracia. "Esta esfera pública é, nos países capitalistas, sinônimo da democracia, simultânea ou concomitante, e ao longo do tempo os avanços sociais que mapeavam o acesso e a utilização do fundo público entraram num processo de interação com a consolidação de instituições políticas democráticas. Para todos os efeitos, pode-se considerar a construção da esfera pública e a democracia representativa como irmãos siameses"86.

O alargamento da esfera pública é a ampliação da democracia representativa, ao mesmo tempo que o avanço desta última abre o espaço institucional que possibilita cada vez mais uma publicização das relações sociais. Este processo provavelmente levará ao controle coletivo da utilização do fundo público que,

82 HOBSBAWM, E. J. O eurocomunismo e a longa transição capitalista . In Encontros com a Civilização Brasileira, nº4, Rio de Janeiro, Civilização Brasileira, 1978. p. 226-232.

${ }^{83}$ Há inúmeras discussões sobre esta questão: RADICE, L.L. Um socialismo a inventar. São Paulo, Brasiliense, 1982.

BOFFA, M. et. al. O Marxismo e o Estado. Rio de Janeiro, Graal, 1979. INGRAO, P. Crisi e rinnovamento dello stato. In Rinascita, n50 e 51, Roma, Dez. 1977. INGRAO, P. Massa e potere. Roma wiuniti, 1977

${ }^{84}$ ZANGHERI, op. cit. p. 231.

${ }^{85}$ HABERMAS, J. A nova intransparência. Novos estudos, no 18, São Paulo, Cebrap, Set. 1987, p. $103-114$.

${ }^{86}$ OLIVEIRA, F. de O surgimento do antivalor. Novos estudos, № 22, São Paulo, Cebrap, Out. 1988. p. 21 
por sua vez, modificará o Estado e toda a forma de produção. A análise posta nestes termos reafirma a importância da democracia na luta pelo socialismo. Tomando a política como um dado estrutural, a indissociabilidade entre socialismo e democracia tem no movimento dos trabalhadores o seu fundamento.

\section{4 - Considerações finais}

O debate sobre a relação socialismo e democracia esteve presente no pensamento socialista durante todo o século $X X$, a busca de uma relação necessária entre os dois perpassou todo o processo de sua constituição. Praticamente, em nenhum momento, ocorreu um total abandono da perspectiva que apontava para uma consubstancialidade entre socialismo e democracia.

As discussões dos social-democratas no início do século, dos socialistas adeptos da planificação na década de 1930 e de inúmeros expoentes do pensamento socialista na Europa, após a década de 1950, tinham um ponto básico em comum: a defesa da necessária relação entre socialismo e democracia.

Não se está afirmando que todo movimento socialista considerou a democracia como fundamental na edificação do socialismo. Os segmentos de orientação leninista, Trotskysta, etc., sempre lidaram com a democracia com absoluto desdém, reduzindo-a a pura hipocrisia da classe burguesa.

A tentativa de mapear as principais discussões sobre a relação socialismo e democracia teve o objetivo de demonstrar que elas não se afastavam do marxismo do ponto de vista teórico por estarem trabalhando a questão da democracia, impuseram, sim, a necessidade de não equalizar democracia e capitalismo. Esta foi uma grande herança que os social-democratas deixaram para todo o pensamento socialista.

A social-democracia, da primeira metade deste século, ao afirmar que a classe trabalhadora se transformaria em maioria política apontava para um não reducionismo tanto na questão do Estado quanto da democracia.

REZENDE, M.J. de. Democracy from the perspective of some marxist theorists. Semina:

Ci. Sociais/Humanas, Londrina, v. 17, n. 3, p. 274-285, Sep. 1996.

ABSTRACT: This article charts the main views of some marxist theorists about democracy and its relationship with socialism. Based on reflections developed during the first half of the 20th century, attempts to elucidate the peculiarities of a very strong debate that took place at that time have been made. This provided the elements to understand the fundamental issues that were raised during the second half of this century by part of the western socialist movement. This movement gave great emphasis to the necessary imbrication between political democracy and socialism.

KEY-WORDS: Democracy, socialism, the state, capitalism, working class, political institutions, representation.

\section{5 - BIBLIOGRAFIA}

ADLER, M. Democrazia e consigli operai. Roma, Riuniti, 1970.

Democrazia política e democrazia socialle. Roma, 1945.

CERRONI, V. Teoría política y socialismo. México, Era, 1976.

COLE, G.D.H. História del pensamiento socialista. V.3. México, Fondo de cultura económica, 1985.

DELLA VOLPE, G; HAVERMANN, R; LONGO, L. Socialismo $\theta$ democracia. Encontros com a Civilização Brasileira, $n$ ำ15, Rio de Janeiro, Civilização Brasileira, 1979.

ESPING-ANDERSEN, G. As três economias políticas do welfare state. Lua nova, no 24, São Paulo, Cedec, Set. 1991.

FAUSTO,R. Marxismo e democracia. Fortaleza, UFC,NEPS, 1980. Estudos, ํo 18.

GERRATANA, V. et al. Consejos obreros y democracia socialista. México, Siglo XXI, 1977.

HOBSBAWM, E.J. et al. Dossier sobre o eurocomunismo. Encontros com a Civilização Brasileira, n4ㄴ, Rio de Janeiro, Civilização brasileira, 1978.

(org). História do Marxismo. Vs. 2, 3, 5, 8, 11 e 12. Rio de Janeiro, Paz e Terra, 1982, 1984, 1985, 1987, 1988, 1989. (Os textos que foram utilizados, neste trabalho, desses volumes foram citados sob forma de notas de rodapé no transcorrer do trabalho).

HABERMAS, J. J. A nova intransparência. Novos Estudos no 18, São Paulo, Set.1987.
KAUTSKY, K. A ditadura do proletariado. São Paulo, Ciências Humanas, 1979

e TROTSKY, L. Terrorismo y comunismo. Madrid, Júcar, 1977

KING, D. As estruturas do welfare state. Novos Estudos, $n-22$ São Paulo, Cebrap, Out.1988

LÊNIN, V. I. El estado y la revolucíon. Buenos Aires, Anteo, 1973.

A revolucão proletária e o renegado Kautsky. São Paulo, Ciências humanas, 1979.

LUXEMBURGO, R. Escritos políticos I. México, Era, 1978.

OLIVEIRA, F. de $O$ surgimento do antivalor. Novos estudos, $n^{\circ}$ 22, São Paulo, Cebrap, OUT.1988.

PRZEWORSKI, A. Capitalismo e social-democracia. São Paulo, Cia das letras, 1989

e WALLERSTEIN, M. O capitalismo na encruzilhada. Novos Estudos, ํำ22, São Paulo, Cebrap, Out. 1988

RADICE, G. Socialismo democrático. Rio de Janeiro, Zahar, 1967.

RADICE, L.L. Um socialismo a inventar. São Paulo, Brasiliense, 1982

TOGLIATTI, P. Socialismo e democracia. Rio de Janeiro, Ilha, 1980. 